\title{
SERGIUS KODERA
}

\section{RENAISSANCE READINGS OF THE MYTH OF ARISTOPHANES FROM PLATO'S SYMPOSIUM (189C-193D): MARSILIO FICINO, LEONE EBREO, GIORDANO BRUNO}

For more than a century Ficino's commentary on the Symposium (1469) was imitated by several authors who wrote philosophical treatises on love that circulated widely among European readers. ${ }^{1}$ It is curious and interesting, for the transmission of works and their interpretation, that Plato's text on love, filled as it was with implicit and explicit homoeroticism, should have had such a profound impact on sixteenth-century Italian culture. Indeed, the transformation of Platonic erotic doctrines into something compatible with the moral standards of both Christianity and Judaism is a fascinating chapter in the history of the domestication of pagan discourse and a textbook case of deliberate misreading. This article examines three Renaissance philosophers-the Christian Neo-Platonist Marsilio Ficino (1433-99), the Sephardic Jew Leone Ebreo (ca. 1480 - ca. 1520), and the radical thinker Giordano Bruno (1548-1600)—in order to discuss their respective interpretations of a crucial speech in the Symposium: Aristophanes' account of the myth of the birth of love, the myth of primordial beings. The assimilation of this part of the Symposium was especially difficult for the Christian and the Jewish traditions because in this passage Plato speaks approvingly of homosexuality and lesbianism, thus outlining a Greek anthropology relating to the Athenian city state vastly different from that of later societies. ${ }^{2}$ In commenting and attempting to

$1^{1}$ This article was originally written for a conference on "Sexualities and Knowledges" organized by Margurite Waller and held at the University of California, Riverside, 22-24 February 2002. An earlier version was presented at a workshop held at the University of Vienna in June 2000. I wish to thank Alice Pechriggl, Valery Rees, Marguerite Waller and Konrad Eisenbichler as well as several anonymous reviewers for their encouraging remarks, criticisms, and valuable suggestions.

${ }^{2}$ The terms homoerotic and heterosexual are no doubt anachronistic; in the present context, they are meant only to denote sexual relationships between males or between men and women and they do not refer to the constitution of subjective identities. In his ground breaking study on homosexuality and male culture in Renaissance Florence, Michael Rocke characterizes the situation as fol- 
integrate such passages from an (otherwise welcomed) pagan authority into their own cultural environment, the authors under consideration felt obliged to spell out their own ideas about the relationships between the sexes, as well as the links between bodies and minds. In that context, Jews and Christians alike fell back on philosophical anthropologies that were more akin to their own respective discursive formations.

\section{Plato in the Renaissance}

To start with some well-known, but fundamental facts about the transmission of Plato's works, it should be recalled that during the Middle Ages few genuine texts from Plato were accessible in Latin, with the notable exception of parts of the Timaeus, in the versions of Cicero and Chalcidius. Nevertheless, Platonic philosophy had a very fine reputation among Christians, due in part to the praise that the perhaps most influential church authority, Augustine, gave to this pagan philosopher. In the City of God, we read that Plato was "nearer to the truth than the whole ancient troop of philosophers." 3 This positive assessment must have contributed largely to the high esteem in which Plato was held at the beginning of the fourteenth-century (and indeed before). One prominent example is Petrarch (1304-74), who is reported to have obtained from Byzantium a Greek manuscript of Plato's dialogues; although it was one of his most treasured belongings, Petrarch had no Greek and, though he tried, was unable to find a translator for it. ${ }^{4}$ It was only with Leonardo Bruni (ca. 13691444), chancellor of the Republic of Florence and one of the foremost humanists of his day, that the Renaissance translation of Platonic works began. Bruni was modeling Plato into the foremost theoretician of vita

lows: "Some scholars, if they have not simply assumed that males who had sex with other males in this period were exclusively 'homosexual,' have adopted the seemingly more appropriate word 'bisexuality' to characterize men's interest in both sexes. But this anachronistic term is only a hybrid product of the sharply drawn contemporary categories 'homosexual' and 'heterosexual,' which were lacking in this society, and it probably misrepresents the cultural specificity of late medieval and early modern understandings of erotic experience and sentiment." (124) See also below.

3 Augustine, City of God, 8, 5-11. For a more ambivalent assessment of Platonism by Augustine see his Confessions, 7, 9. The story of the reception of Platonic texts during the Renaissance has been told in great detail by Hankins, Plato in the Renaissance.

${ }^{4}$ Copenhaver/Schmitt, Renaissance Philosophy, 127-128; Hankins, Plato in the Renaissance, 1:25-26.; Kristeller, Eight Philosophers, 11. 
activa, or active life, a kind of cultural hero of the Ciceronian brand characteristic of much of fifteenth-century humanism. But Bruni only paraphrased parts of the Symposium. What was actually so difficult about the speech of Aristophanes?

\section{Aristophanes' speech}

In Aristophanes' speech in the Symposium, Plato recounts a story about the origin of love and sexual desire. In the old days, he states, there were three species of human beings, not just two: double males, double females and a sort of mixed species; they had four hands and legs, two sets of genitals with a single head and two faces (189 DE), their shape was round, complete, forming a circle. The males descended from the sun, the females from the earth, and the mixed, androgynous sex was under the patronage of the moon. These people were twice as strong as ordinary people and were able to move effortlessly, as they supported themselves with their eight limbs, moving rapidly around and around in circles (190A). ${ }^{5}$ In this state of frightful power the primordial double humans decided to assault the Olympians, who-after some deliberation-decided not to kill their attackers (because otherwise there would have been no one left to worship the gods) but rather to punish and weaken them permanently by cutting them in halves, (190B-D). The effects were disastrous: "It was their very essence that had been spliced into two; so each half missed its other half and tried to be with it; they threw their arms around each other and longed to be grafted together. As a result, [...] they died of starvation and general apathy" (191A). As a remedy for this situation (and to prevent humans from dying out) Zeus ordered Mercury to move the genitals of the sliced halves to their front side, thus enabling them to have sex or, in the case of homosexual relationships, at least to relax and to continue living in a more balanced emotional state: "male female relationships leading to procreation and offspring, male relationships would at least involve sexual satisfaction, so that people would relax, get on with their work, and take care of other aspects in life" (191D). ${ }^{6}$

5Plato, Symposium, trans. Waterfield, 27. Ficino translates this and the following passages, Plato, Opera omnia, 1602, (1186B) as: "Postquam natura hominum ita divisa fuit, cum quisque dimidium sui agnitum cuperet, inter se concurrebant, circumiactisque brachiis se invicem complectebantur, conflari unum affectantes. Unde fame et torpore deficiebant [...]."

6Plato, Symposium, trans. Waterfield, 28; Plato, Opera omnia, 1602, 1186CD: "[...] per masculum quidem in foemina, hac de causa, ut si in amplexu vir foeminae commisceretur, genita prole speciem hominum propagarent. Sinautem 
The desire for sexual union functions here as a substitute for a primordial unity, which remains, however, unrecoverable. Men and women descending from the mixed race are heterosexual, producing the highest quantity of adulteresses and adulterers respectively.

Any women who are offcuts from the female gender aren't particularly interested in men. They incline more towards women and therefore lesbians come from this group. (191E)

And any men who are offcuts from the male gender go for the males. While they're boys, because they're slices from the male gender, they fall in love with men, they enjoy sex with them, and they like to be embraced by them. These boys are the ones who are outstanding in their childhood and youth, because they are inherently more manly than others. I know they sometimes get called immoral, but that's wrong: their actions aren't prompted by immorality, but by courage, manliness, and masculinity. [...] there's good evidence for their quality: as adults, they're the only men who end up in government. $(192 \mathrm{~A})^{8}$

In an important shift, in this passage Plato links sexual orientation to the political structure of classical Athens, a city governed by a small number of men who practiced a sort of ritualised homosexuality that was intimately related to the maintenance of power. ${ }^{9}$ There is probably no need to highlight what sort of feelings this apology of male homosexuality, as well as the acknowledgement of lesbianism, might have induced in Renaissance Christians and Jews alike. The value of heterosexuality, the only possible

masculo masculus, satietate ab amplexu amoverentur, et ad res gerendas conversi victum, curarent."

7Plato, Symposium, trans. Waterfield, 28; Plato, Opera omnia, 1602, 1186E: "Quae vero mulieres mulieris pars existunt, haud multum viros desiderant, sed foeminas magis affectant, atque hinc foeminae quae foeminas cupiunt nascuntur."

8 Plato, Symposium, trans. Waterfield, 28; Plato, Opera omnia, 1602, $1186 \mathrm{E}$ 1187A: "At vero qui maris portio sunt, mares sequuntur. At dum pueri sunt, utpote qui maris particula sunt, viros diligunt, virorumque familiaritate assidua congressuque gaudent: hique sunt puerorum adolescentulorumque omnium generosissimi, quippe per natura prae caeteris omnibus sunt viriles. Hos quidam impudicos falso apellant. Neque enim impudentia ulla, sed generositate, \& fortitudine quadam mascula virilique natura hoc agunt [...]. Huius evidens argumentum est, quod cum adoleverint, soli ad civilem administrationem conversi viri praestantes evadunt [...]."

"Waterfield in: Plato, Symposium, trans. Waterfield, XV-VI.; Halperin, "Why is Diotima a Woman?" passim. 
form of intercourse (and only with procreative intentions), ${ }^{10}$ on the other hand, is parodied in Aristophanes' speech.

Renaissance readers had to domesticate the text if they wanted to continue to study Plato or to use his texts as a support for their own ideas: how could they assimilate such passages into their own cultural background without discrediting Plato forever, let alone endorse him as the most Christian of all pagan philosophers? In fact, even for modern readers it has been notoriously difficult to assess the tone of Aristophanes' speech, or even to give a consistent and convincing interpretation of the story: is it intended as mere parody, or more of an Aesopian fable, and if so, what sort of morals are to be construed from the narration? To what extent are genuine Platonic concepts about Eros embedded in the narration? What are we to think of the idea that sexuality is inborn and hereditary? ${ }^{11}$ It is, of course, far beyond the scope of this article to treat these issues. One aspect of the Aristophanes myth that was as attractive as it was mysterious to Renaissance and modern readers alike, is the idea that sexuality is actually a substitute, ersatz, for a primordial unity of some sort that has been lost for good, a kind of emotional sensation. According to Plato, lovers "obviously have some other objective, which their minds can't formulate; they only glimpse what it is and articulate it in vague terms" (192CD). ${ }^{12}$ Here Eros becomes a signifier for the pursuit of lost primordial wholeness, which allows the matching halves to desire such close proximity that they would

${ }^{10}$ See, for example Ficino, Commentaire sur le Banquet, VI, 14: 229-230; see also below.

${ }^{11}$ See Guthrie, A History of Greek Philosophy, IV: 384; Waterfield in Plato, Symposium, trans. Waterfield, XXIII-IV; Nehamas, Virtues of Authenticity, 307, provides a good example of a contemporary assessment of this text: "Aristophanes' speech is stunning in its originality. Although it contains parody in its use of myth, it is on the whole a highly serious work, and its view of love has no parallel in earlier Greek literature. It actually anticipates more romantic versions of love, particularly the idea that love draws together two unique individuals to join as one person. For all its comic elements, a sad note sounds frequently in the speech: the goal of loving, the forging of one person out of two, is not to be achieved. What we have instead is the temporary satisfaction of sexual relationships, and these are at best a promise of a more permanent happiness and a closer union."

12Plato, Symposium, trans. Waterfield, 28-9; Plato, Opera omnia, 1602, 1187B: "Aliud quiddam est profecto, quod animus utriusque cupit, nec exprimere valet, sed vaticinatur potius conijcitque, et affectum insitum vestigiis signat obscuris." See also Halperin, "Platonic Erôs," 67-69. 
even gladly let Hephaestus, ${ }^{13}$ the divine blacksmith, bind and fasten them together for eternity. This longing cannot be induced by sex or physical attraction alone, but only by some sort of desire for an ontologically higher unity (192DE).

On the other hand, such noble and high-flying ideas in the truest sense of the word are counterbalanced by the satirical mood characteristic of Aristophanes' tale: quite humorous (to modern readers, at least) is, for instance, the divine threat to the halved humans that if they continue to misbehave they would be divided once more, "and in that mode of existence we'd be no different from those profiles on tombstone, sawn in two down the line of our noses" (193A). ${ }^{14}$ To Marsilio Ficino, this threat would be an integral part of the divine mysteries hidden behind the profane text.

\section{Marsilio Ficino's Psychological Reading}

Marsilio Ficino, the first translator of the complete works of Plato into Latin (published 1484), was a key figure in the transmission of Platonism to the Latin west after the Middle Ages. In addition, Ficino wrote sometimes lengthy commentaries or introductions to Plato's works, in which his key objective was to endorse Plato as a sort of Attic Moses who wrote in Greek and formed part of a larger group of prisci theologi (ancient theologians) whose doctrines could be interpreted as forebears of the truths of Christian doctrine. ${ }^{15}$ Ficino's translation of Plato was influential until the nineteenthcentury and is faithful to the text. ${ }^{16}$ The following discussion will focus on Ficino's commentary on the Symposium, the Commentarium in convivium Platonis, De amore, one of his most successful works, where the Author tries to cover up the difficult passages of the myth of Aristophanes. ${ }^{17}$

The fourth book of the De amore is devoted to Aristophanes' speech. From the very beginning Ficino emphasizes the difficulty and alleged obscurity of this passage, which calls for special interpretative methods to

13 This is, of course, an ironic allusion to the way in which Hephaestus welded his unfaithful wife Aphrodite together with her lover Ares in a hunting net to expose the adulterous couple to the derision of the gods (Odyssey 8. 266-367).

${ }^{14}$ Plato, Symposium, trans. Waterfield, 29; Plato, Opera omnia, 1602, 1187D: "[...] talesque efficiamur, quales qui in columnis figurantur, nares secti evadamus similes [...]."

${ }^{15}$ Copenhaver/Schmitt, Renaissance Philosophy, 155; Allen, "Ficino's Theory," passim.

${ }^{16}$ For a positive assessment of the quality of Ficino's translations, see Hankins, Plato in the Renaissance, 1:311-313.

17 See Hankins, Plato in the Renaissance, 2:484 on editions and dates of composition for this work. 
read the story of the primordial humans. Unlike his commentaries on the other speeches of the Symposium, in this case Ficino retells the myth in its entirety. This allows him to omit some of the most unassimilable passages: the encomium of homosexual men, and Zeus moving the sexual organs of the halved humans to their front side. Only a half sentence alludes to divergent sexual orientations: "Everyone therefore is looking for his other half, no matter to which sex he feels attracted, and gets very excited when he meets it $[\ldots] . " 18$

Ficino then takes another step which provides him with a theoretical basis to domesticate the pagan text in its entirety: referring to the authority of Augustine, he claims that it is indispensable to read the myth as an allegory in order to discover the divine mysteries that lie under the veil of the figments of the text. ${ }^{19}$ In that process it is possible to avoid interpreting all the items reported in the story, because many details are introduced only to allow for the ordering and the connection of disparate and difficult, and hence divine, truths. Even obscenity may turn out to be a safeguard against profanation. In that context, Ficino links allegorical reading metaphorically to a tool, the iron part of the plough used to turn the earth and, therefore, the essential element to which other (non-essential) parts are added.

For it was the custom of the ancient theologians to conceal their holy and pure mysteries in the shadows of metaphors, lest they be defiled by the profane and impure. [...] For even Aurelius Augustine says that not all the things that are represented in figures must be thought to mean something. For many things are added for the sake of order and connection, on account of the parts that do mean something. Only by the ploughshare is the earth turned, but in order that this can be done, other parts too are joined to the plough. ${ }^{20}$

18 Ficino, Commentaire sur le Banquet, IV, 2:167-168: "Quotiens itaque dimidium suum alicui cuiuscumque sexus avidus sit occurrit, vehementissime concitatur [...]" (Symposium 191A).

${ }^{19}$ On Ficino and allegorical reading, see, for instance, Copenhaver/Schmitt, Renaissance Philosophy, 155-6; Hankins, Plato in the Renaissance, 1:343-347.

${ }^{20}$ Ficino, Commentary on Plato's Symposium, 72-73; Ficino, Commentaire sur le Banquet, IV, 2:169: "Mos enim erat veterum theologorum sacra ipsorum puraque arcana, ne a prophanis et impuris polluerentur, figurarum umbraculis tegere. [...] Nam et Aurelius Augustinus non omnia inquit, que in figuris finguntur, significare aliquid putanda sunt. Multa enim propter illa que significant ordinis et connexionis gratia sunt adiuncta. Solo vomere terra proscinditur sed, ut hoc fieri possit, cetera quoque huic aratri membra iunguntur." 
But allegorical exegesis is not the sole strategy for avoiding some of the more difficult passages in Aristophanes' speech. Ficino also makes the reader believe that his own synopsis of the myth is actually the genuine and complete Platonic text on which he subsequently comments verbatim.

Men formerly had three sexes: masculine, feminine, and mixed, the sons of the sun, the earth, and the moon. And they were whole. But on account of pride, when they wished to equal God, they were cut in two; if they are proud again, they are to be split in two parts again. The division having been made, half is drawn to half by love, in order that the restitution of wholeness may be effected. This achieved, the race of men will be blessed. ${ }^{21}$

This stratagem, not uncommon in Ficino's allegorical interpretations, allows for a reading of the physical details of Aristophanes speech as allegories for the fate of the human soul:22

Men, that is, the souls of men, formerly, that is, when they are created by God, are whole, they are provided with two lights, one innate and the other infused, in order that by the innate light they may perceive inferior or equal things, and by the infused, superior things. They wished to equal God. They turned themselves toward the innate light alone. Hence they were divided. They lost the infused splendor when they were turned toward the innate light alone, and they fell immediately into bodies. If they become more proud, they will be divided again, that is, if they trust too much to the natural power, that innate and natural light which remains will be extinguished in some measure. ${ }^{23}$

${ }^{21}$ Ficino, Commentary on Plato's Symposium, 73; Ficino, Commentaire sur le Banquet, IV, 2:168-169: "Homines quondam tres sexus habebant, masculinum, femininum, promiscuum, solis, terrae, lunaeque filios. Erant et integri. Sed propter superbiam, cum deo equare se vellent, scissi in duo sunt, iterum si superbiant, bifariam discindendi. Sectione facta, dimidium amore ad dimidium trahitur, ut integritatis restitutio fiat. Qua completa, beatum genus hominum est futurum."

${ }^{22}$ Hankins, Plato in the Renaissance, 1:355 says accordingly: "[...] when Plato seems to be praising something we abhor, he is in fact praising a purified and heavenly form of it which we, with our earthly vision, are not able to see."

23 Ficino, Commentary on Plato's Symposium, 73; Ficino, Commentaire sur le Banquet, IV, 2:169: "Homines, id est, hominum animae. Quondam, id est, quando a deo creantur. Integrae sunt, duobus sunt exornate luminibus, ingenito et infuso. Ut ingenito equalia est inferiora, infuso superiora conspicerent. Deo equare se voluerunt. Ad unicum lumen ingenitum se reflexerunt. Hinc divise sunt. Splendorem infusum amiserunt, quando ad solum ingenitum sunt converse sta- 
According to Ficino, Aristophanes' myth is an allegory for a condition of the soul and points to a mental process. The split of the primordial humans signifies the loss of the divine ray of light, the supernatural intellect. Equipped solely with their other half, natural reason, humans are confronted with the task of regaining their connection with the numinous. In these circumstances, Aristophanes's speech becomes an allegory for the soul's descent into matter and its subsequent regaining of the beatific vision through ascent to the divine. The way back, upwards, so to say, is powered by Eros. (Here Ficino's reading of Aristophanes' tale refers to the divine cavalcade in Plato's Phaedrus, a central myth for Ficino's theory of love. $)^{24}$

The division having been made, half is drawn to half by love. When souls, already divided and immersed in bodies, first have come to the years of adolescence, they are aroused by the natural and innate light which they retained (as if by a certain half of themselves) to recover, through the study of truth, that infused and divine light, once half of themselves, which they lost in falling. This once recovered, they will be whole and blessed with a vision of God. ${ }^{25}$

The main thrust of Ficino's reading rests on the claim that the myth of the double humans does not refer to the entire physical human being, but rather exclusively to soul, which in the Neoplatonic hierarchy of being is clearly superior to bodies. "When Aristophanes said men, he meant our souls, in the Platonic way." 26 This reading has important consequences for Ficino's philosophical anthropology. Severing bodies from souls, Ficino's

timque in corpora cecidere. Superbiores facte iterum dividentur, id est, si naturali nimium confidant ingenio, lumen illud ingenitum et naturale quod restitit quodammodo extinguetur." For an interesting parallel in Giovanni Pico della Mirandola see his Commento sopra una canzona de amore II. 4: 527-529, together with Wind, Pagan Mysteries, 200-202.

${ }^{24}$ Allen, The Platonism of Marsilio Ficino, 88-111, esp. 105, 111, 166. On the interpretation of the myth of the divine cavalcade see also Ficino, Commentaire sur le Banquet, 7. 14: 259-260.

${ }^{25}$ Ficino, Commentary on Plato's Symposium, 73; Ficino, Commentaire sur le Banquet, IV, 2:169: "Sectione facta, dimidium amore ad dimidium trahitur. Animae iam divisae et immersae corporibus, cum primum ad annos adolescentiae venerint, naturali et ingenito lumine quod servarunt, ceu sui quodam dimidio excitantur ad infusum illud divinumque lumen olim ipsarum dimidium, quod cadentes amisere, studio veritatis recipiendum. Quo recepto iam integrae erunt et dei visionae beatae."

26Ficino, Commentary on Plato's Symposium, 75; Ficino, Commentaire sur le Banquet, IV, 3:171: "[...] cum homines Aristophanes nominavit, more platonico animas nostras significavisse." 
sweeping and, even for him, rather unusual claim that Aristophanes' myth refers exclusively to souls lends his anthropology an almost Cartesian tendency.

Hence, Man is said to procreate, nourish, grow, run, stand, sit, speak, make works of art, feel and understand. But all these things the soul itself does. And for this reason the soul will be Man. [...] the soul, as father and creator of the body, begets, feeds, and nourishes. ${ }^{27}$

He maintains that the soul is the essence of the human being, whereas the body becomes a mere (and thus) dispensable attachment, generated by soul itself. In that case, the author argues, the content of Aristophanes' myth could not refer to bodies; instead of physiology, the story is about psychology. In this reading, the soul instrumentalizes the body in its entirety, an interpretation which is in blatant contradiction to Aristophanes' description of erotic physical desire leading towards the spiritual realm and thus reuniting the torn soul. Moreover, and as a corollary, according to Ficino the drama of the splitting in half of the primordial humans signifies the descent of soul into the physical world: here the lower part of the soul thinks of itself as sovereign, which only the creator himself can be, and hence is punished by loosing its higher light. This is the meaning of the revolt of the primordial beings against the Olympians in Aristophanes' speech.

But our soul fell into the body when, neglecting the divine light, it used its own light alone and began to be content with itself. Only God, to whom nothing is lacking, above whom there is nothing, remains content with Himself, sufficient to Himself. Therefore the soul made itself equal to God when it wished to be content with itself alone, as if it could be sufficient to itself no less than God.

Aristophanes says that this pride was clearly the cause of the soul, which was born whole, being split, that is, with regard to its twin lights; after this it used one but neglected the other. Plunged into the abyss of the body as though into the river Lethe, and forgetting itself for a time, it is seized by the senses and lust, as though by police and a tyrant. But when the body has matured, and the instruments of the senses have been purged, with learning contributing, the soul wakes up a little. Here the

27Ficino, Commentary on Plato's Symposium, 74; Ficino, Commentaire sur le Banquet, IV, 3: 170-171: "Hinc generare, nutrire, augere, currere, stare, sedere, loqui, artis opera fabricare, sentire, intelligere homo asseritur. Omnia vero haec anima ipsa facit. Ideoque anima erit homo. [...] anima tamquam pater et artifex corporis ipsum gignit, auget atque nutrit. " 
natural light shines forth and searches out the order of natural things. By this investigation the soul perceives that there is some architect of this huge machine. And it desires to see and possess Him, [... . But this instigation and appetite is true love $[\ldots] .28$

Aristophanes' narration explains why we feel erotic desire, a drive that is physical but nevertheless transcends the body, and hence underscores the intimate connection between bodies and souls. Ficino is unable to deal with this idea because in his conceptual framework there is no place for a positive assessment of physical desire, let alone for non-reproductive forms of sex as vehicles to discover the transcendent. In this interpretation of Aristophanes' myth, the body is excluded and discarded as an impediment to spiritual fulfillment from the beginning.

Ficino's reading is propelled by his urgent need to eradicate the pagan anthropology expressed in Plato's text. In that process Ficino transposes the splitting in half of the primordial humans from the level of the body, as in Aristophanes' narration, to a phenomenon relating to higher and lower parts of the soul. Ficino therefore translates the violence of the original separation of two bodies into a psychological process. An important corollary to this formulation is that the human being is now defined in terms of its soul, which entails a radical separation between bodies and minds. Such a clear division stands not only in sharp contradiction to contemporary Aristotelianisms, ${ }^{29}$ but even to ideas Ficino himself expresses in other writings, where the emphasis is on a gradual transition from the bright intellectual forms to the darkness of matter, with soul in the centre of Creation. 30

The price of domesticating the pagan myth is high indeed: it amounts

29 On which, see for instance Keßler (2001).

${ }^{30}$ For the author's doctrine of spiritus, more or less embodied garments of the soul, see Walker, Spiritual and Demonic Magic, Ficino, Three Books on Life, 41-42 (introduction to the De vita libri tres) and ibid. III, 3: 256 : "Ipse [sc. Spiritus] vero est corpus tenuissimum, quasi non corpus et quasi iam anima, item quasi non anima et quasi iam corpus." See also ibid. III, 26: 384-385: [Mundus est] [...] non solum corporeus, sed vitae insuper et intelligentiae particeps. Quamobrem praeter corpus hoc mundi sensibus familiariter manifestum latente in eo spiritus corpus quoddam [...]. In spiritu viget anima; in anima fulget intelligentia. Atque sicut sub Luna nec miscetur aer cum terra, nisi per aquam, nec ignis cum aqua, nisi per aerem, sic in universo esca quaedam sive fomes ad animan corpori copulandum est ille ipse quem spiritum apellamus." Ficino, Théologie platonicienne, III, 137: "[...] anima [...] in medio mentium corporumque confinio creata est." Ibid. III: 153: “[...] anima verissimum omnium, quae a Deo componuntur, medium, [...] in ea, ut caetera praetermittam, part- 
to nothing less than the complete substitution of Plato's anthropology by a construct which is seemingly more compatible with Ficino's own discursive formation. His reading emphasizes, even exaggerates, the difficulties that many Christian writers had in attempting to assess the position of the sexual body in Creation.

By linking the myth of the ascent of the soul in Plato's Phaedrus, Ficino's interpretation completely neglects the catch-line of Aristophanes' speech, namely that our longing to be united with our original halves will never be gratified, and that sex is just a pale imitation of our original unity. However, since Ficino cannot retell the myth in its full physical detail, he is consequently unable to adapt this line of thought, which might in fact have been very appealing to Christians. So, it is no wonder that the author assumes-in blatant contradiction to the original text-that Eros acts as a leveler of desire, who even has the ability to appease or fulfil all wishes. Hence, by confounding Eros with philia, Ficino identifies both terms with spiritual redemption.

Therefore by the beneficence of Love it is brought about that among the various degrees of bliss each is content with his own portion without any envy. It also happens that souls enjoy the same feasts eternally without any satiety. ... Therefore, to sum up briefly, we shall praise three benefits of Love: that by restoring us, formerly divided, to a whole, he leads us back to heaven; that he assigns each to his own seat, and makes all content in that distribution; that, all distaste removed, by a certain love of his own he perpetually kindles the pleasure as if new in the soul and renders it blessed with enticing and sweet fruition. ${ }^{31}$

ibile impartibili, alterum eodem, motus statu quasi actum gravi harmonice temperatur." A related phenomenon is to be found in Ficino's theory about the salutary powers of the color green, which he says is the mean between the two extremes black and white; Ficino, Three Books on Life, II, 14: 405. On the importance of the principle of mediation in Ficino in general, see Kristeller, The Philosophy of Marsilio Ficino, 101-102. On the principle of mediation in his magic and cosmology, see Ficino, Three Books on Life, 41, with references.

${ }^{31}$ Ficino, Commentary on Plato's Symposium, 80; Ficino, Commentaire sur le Banquet, IV, 6: 177: "Quapropter amoris beneficio factum est ut in diversis felicitatis gradibus portione sua quilibet sine ulla invidia sit contentus. Fit etiam ut sine ulla sacietate animi iisdem vescantur dapibus in eternum. [...] Tria igitur ut brevi complectar amoris beneficia collaudabimus: quod nos olim divisos in integrum restituendo reducit in celum, quod suis quemque collocat sedibus facitque omnes in illa distributione quietos, quod omni expulso fastidio, suo quodam ardore oblectamentum quasi novum iugiter accendit in animo redditque illum blanda et dulci fruitione beatum." 
This reading allows Ficino to eclipse all gendered aspects of the myth: it is not men, women, or androgynes, longing for each other's halves anymore; instead, all sorts of non-sexual (and hence, male) disembodied souls are desirous of immaterial divine virtues which enable them to regain divine unity on their way back to the godhead. As a consequence, Ficino aims at merely spiritual relationships between male souls, non-sexual friendships which, to a limited extent, reflect Aristophanes' encomium of homosexual men. Love for young men is engendered by an inborn or acquired desire for immortal and higher learning which is aptly directed toward male friends, simply because they are more intelligent than women. Again we see how Ficino's text, although seemingly far removed from the body and its physical aspects, nevertheless very stringently argues for a body politic that marginalizes women and reduces any relationship to them to the comparatively inferior level of the generation of offspring.

But some, either by nature or by education, are better fitted for progeny of the soul than of the body, and others, certainly the majority, the opposite. The former follow heavenly love, the latter, vulgar. For this reason the former naturally love males and certainly those already almost adult rather than women or boys, since in them sharpness of intellect flourishes more completely, which on account of its more excellent beauty, is most suitable for receiving the learning which they wish to procreate. The others the opposite, motivated by the pleasure of sexual intercourse, and the achievement of corporeal reproduction. ${ }^{32}$

After what has been said, it is obvious that, although Ficino's reading displays a tendency to disembody humans, at the same time it establishes hierarchical relationships between men and women. The careful avoidance of physical aspects in Aristophanes' myth does not prevent Ficino from introducing a theoretical framework in which the bodies of women are inferior to those of men. This becomes obvious on the occasion of a remark by Aristophanes (made in passing) that male homosexuals, as descendants

32 Ficino, Commentary on Plato's Symposium, 135; Ficino, Commentaire sur le Banquet, VI, 14: 229: "Ceterum alii vel propter naturam vel educationem ad animi fetus sunt quam corporis aptiores, alii, et quidem plurimi, contra. Illi celestem secuntur amorem, isti vulgarem. Illi natura iccirco mares et illos quidem iam pene adultos potius quam feminas aut pueros amant quoniam in eis magis admodum viget mentis acumen, quod ad disciplinam, quam illi generaturi sunt, propter excellentiorem sui pulchritudinem est aptissimum. Alii contra, propter congressus venerei voluptatem et generationis effectum." 
of the sun, are especially brave. ${ }^{33}$ Ficino claims that all three different kinds of primordial humans actually symbolically reflect divine virtues instilled by God into the soul: the male virtue of courage, which is akin to the sun, the female virtue of temperance, and the androgynous one of justice. In that context, Ficino establishes a hierarchy of the sexes, by stating that the male element is active, the androgynous active and passive, and the female element entirely passive. This is, of course, once again only very distantly related to the original text, where homosexual males were the best pairings while mixed ones belonged to adulterers; Aristophanes does not, however, have much to say about lesbian couples.

The Courage of men we call masculine because of its hardness and boldness. Temperance we call feminine because of a certain restrained and cooler habit of desire and its soft nature. Justice we call mixed. Feminine certainly inasmuch as because of its innocence it brings harm to no one. But masculine inasmuch as it does not permit harm to be done to others, and with very severe judgment levies punishments upon wicked men.

But because it is proper to the male to give and to the female to receive, for that reason we call the sun male, since it receives light from none and gives to all. The moon giving and receiving -receiving from the sun it gives to the elements-we call mixed. And the earth, since it certainly receives from all and gives to none, we call female. ${ }^{34}$

It is rather amusing to learn that the female, procreative element in this account "gives" to none; this seems to be so extravagant an idea that it can be read only as an unintentional allusion to the lesbians in Aristophanes' myth.

33 The celestial origin of the different sorts of primordial human beings fitted well into the more general theory that love between individuals was actually engendered by analogous celestial origin and was hence due to cosmic causes: see Ficino, Commentaire sur le Banquet, IV, 5: 174.

${ }^{34}$ Ficino, Commentary on Plato's Symposium, 77-78; Ficino, Commentaire sur le Banquet, IV, 5: 174 : "Fortitudinem hominum masculam propter rubor et audaciam nuncupamus. Temperantiam, feminam, propter remissum quemdam et frigidiorem desiderii habitum miteque ingenium. Iustitiam, promiscuam. Feminam quidem prout innocentia sua iniuriam infert nemini. Masculam vero prout aliis inferrri non sinit et severiori censura in homines iniquos animadvertit. Quia vero maris dare, feminae suscipere proprium est, iccirco solem qui lumen a nullo accipiens exhibet omnibus, marem vocamus. Lunam, quae accipiens a sole, dat elementis, a dando et accipiendo, promiscuam. Terram, cum accipiat quidem ab omnibus, tributa nulli, feminam nuncupamus." For a parallel passage in Pico della Mirandola, see Pico, De hominis dignitate, 530. 
It is only in the sixth book of his commentary on the Symposium (that is, in a place far removed from Aristophanes speech), that Ficino speaks about physical love between men-and only to reject it as an entirely bestial waste of sperm, a crime equivalent to murder.

But since the reproductive drive of the soul, being without cognition, makes no distinction between the sexes, nevertheless, it is naturally aroused for copulation whenever we judge any body to be beautiful; and it often happens that those who associate with males, in order to satisfy the demands of the genital part, copulate with them. [...] But it should have been noticed that the purpose of erections of the genital part is not the useless act of ejaculation, but the function of fertilizing and procreating; the part should have been redirected from males to females. We think that it was by some error of this kind that that wicked crime arose which Plato in his Laws roundly curses as a form of murder. ${ }^{35}$

Ficino's determined rejection of the pagan anthropology outlined in Aristophanes' speech caused him to re-write the entire story. His opposition to the physical forms of same-sex love may well be related to a broader sociological context of fifteenth-century Florence. According to a recent study, the number of individuals in Florence involved in homosexual activities must have been considerable. ${ }^{36}$ Given the implicit misogyny of Ficino's anthropology, it comes as no surprise that he considers virile women to be the most attractive. ${ }^{37}$

35 Ficino, Commentary on Plato's Symposium, 135; Ficino, Commentaire sur le Banquet, VI, 14: 229-230: "Quoniam vero genitalis illa vis animae, utpote cognitionis expers, sexu[u]m nullum habet discrimen, natura tamen sua totiens incitatur ad generandum, quotiens formosum, corpus aliquod iudicamus, contingit plerumque ut qui cum masculis conversantur, quo genitalis partis stimulos sedent illis se misceant. [...] Opportebat autem animadvertere partis illius incitamenta non irritum hoc iacture opus, sed serendi et procreandi officium affectare atque a masculis ad feminas eam traducere. Huiusmodi quodam errore nepharium scelus illud exortum putamus quod in Legibus suis Plato tamquam homicidii spetiem acerime detestatur."

36 Rocke, Forbidden Friendships, 175, estimates that of up to one-third of the fifteenth-century Florentine male population was accused of sodomy. He writes (125): "As an accusation from 1512 suggests, Florentines found nothing at all unusual in the fact that men might desire and have sexual intercourse with both boys and women."

${ }^{37}$ In that context it is interesting to note that in the early sixteenth-century prostitutes in Venice and Florence cut their hair to attract more customers; Rossiaud, Medieval Prostitution, 133. 
Women, of course, catch men easily, and even more easily women who display a certain masculine character. Men catch men still more easily, since they are more like men than women are, and they have blood and spirit which is clearer, warmer, and thinner, which is the basis of erotic entrapment. ${ }^{38}$

On the other hand, and in pointed contrast to Leone Ebreo, whom we will consider next, Ficino is able to open a philosophical perspective on a type of sublimated sexuality that is expressed in intellectual friendships between men. 39

\section{Leone Ebreo, Plato, Moses and the Book of Genesis}

The Dialoghi d'amore, a very popular work during the sixteenth-century, probably written around 1512 but published only in 1535, opens an entirely new perspective on Aristophanes' speech. 40 Its author, Leone Ebreo (Judah Abravanel), was a Jewish philosopher and physician who in 1492 emigrated from the Iberian peninsula to Italy. The Dialoghi is remarkable insofar as it seems to be the first work written by a Jew that extensively refers to Greek mythology. Leone was reacting to Ficino's attempt to portray Plato as one of the prophets of Christianity. As with Ficino before him, for Leone Ebreo, too, Aristophanes' speech served as a pretext for a discussion of his own anthropology. Leone, too, omits important parts of the story, though he recounts Aristophanes' speech in greater detail than his Christian predecessor. This is especially true of the physical details of the primordial humans: in the Dialoghi, one finds a description of the double genitals, the progeny of the male and female halves from sun and earth respectively, and the relationship of the mixed parts to the moon. Leone also reports that the gods refrained from killing the rebellious creatures for fear that no one would worship them anymore, and the subsequent mov-

${ }^{38}$ Ficino, Commentary on Plato's Symposium, 165; Ficino, Commentaire sur le Banquet, VII, 9: 253: "Feminae profecto viros facile capiunt, facilius autem ille quae masculam quandam indolem prae se ferunt. Et tanto facilius masculi quanto similiores sunt viris quam feminae et sanguinem spiritumque habent lucidiorem, calidiorem, subtiliorem, qua in re amatoria consistit illaqueatio."

39 On this kind of friendship, which became famous as "Platonic Love," see Ficino, Commentaire sur le Banquet, II, 8-9; Nelson, Renaissance Theory of Love, 75; Field, The Origins of the Platonic Academy, 195-196; Hankins, Plato in the Renaissance, 1:355; Ebbersmeyer, Sinnlichkeit und Vernunft, Kodera, Filone und Sofia and "Masculine/Feminine."

$40 \mathrm{On}$ the date of the composition of the Dialoghi, see Garvin, The Language of Leone Ebreo's Dialoghi d'amore," 207-210. On the Dialoghi in general, see Perry, "Dialogue and Doctrine"; Perry, Erotic Spirituality, Peri, Die Idee der Liebe. 
ing of their genitals by Zeus in order to avoid the waste of sperm when ejaculate fell on the earth. At this point in the Dialoghi, there is an interpolation which states that out of the semen grew the mandrake, a plant notorious for its connections with magic. ${ }^{41}$ One gets the impression that the Jewish physician was deeply intrigued by Plato's description of surgery to separate Siamese twins. (Ficino, who was also a physician, seems by contrast to have been much less enthusiastic about the anatomic details in Aristophanes' account.)

Swollen with pride at their own strength, they dared to give battle to the gods, to do them hurt and injury. Jupiter, therefore, taking counsel with the other gods, after much deliberation decided that the androgynes should not be destroyed, for in the absence of the human race there would be none to pay honor to the gods; nor yet should their arrogance be left unrebuked, because tolerance would bring insult upon the gods. Therefore he determined to divide them in twain, and he sent Apollo to cut them in half lengthwise and to make of one two, so that they could only walk upright on two feet; and in this way the number of divine worshippers would be doubled. Moreover, Apollo was to warn the androgynes that if they sinned further against the gods, he would return and divide each half into two. And they would be left with one eye and one ear, half a head and face, one hand and one foot, on which they would have to hop along as if lame, and thus would be like figures sculptured on columns in basso-rilievo. Apollo then cut the androgynes in half through the breast and the belly, and turned the faces round towards the side which was cut so that, seeing the incision, man might be reminded of his evil ways and the better observe the section cut off from himself. Over the breast-bone he placed skin, and drew together all parts of the skin which had been cut over the belly and tied then together at the center, and this knot is called the navel. And he left a few winkles round it made by the scars of incision, that seeing them man might remember his sin and punishment. When each part saw that it lacked the other it became desirous of reintegration, and the two came together and were united in close embrace; and thus they stayed, taking neither food nor drink until they perished. For their parts of generation were behind, facing the same way as their shoulders, which before had been the front of

${ }^{41} \mathrm{On}$ the mandrake and its uses in magic, notably as a love-potion, see, for example, Bächtold-Stäubli, Handwörterbuch des deutschen Aberglaubens, I: 318 (sub voce "Alraun"), who reports the belief that this plant grows out of the sperm of hanged men. It could be important for the textual history of the Dialoghi to find a source for this interpolation, because the original speaks of cicadas and Ficino's translation accordingly reads: "[...] sed in terram spargentes semina cicadarum instar concepiebant, atque generabant." Plato, Opera omnia, 1602, 1186 C. 
man, so that they cast their sperm upon the ground, where it bred mandrakes. Jupiter, therefore, seeing that the human race was completely dying out, sent Apollo to turn their genitals to the front of the belly, so that in mutual embrace they might beget their own kind and be satisfied and return to seek what is needful for the preservation of life. 42

In contrast to Ficino's reading, Leone's account of Aristophanes' speech does not suppress the physical content of the myth: sexual intercourse is indispensable for a normal and happy life, hence sex is valuable and, as we shall see, it is the (partial) remedy for division created through original sin. Also in contrast to Ficino, this reading of the Platonic myth allows Leone to repeat Plato's original idea that physical desire is a longing for integration or for a sort of primordial unity.

42Leone Ebreo, The Philosophy of Love, 343-344; Leone Ebreo Dialoghi d'amore, III, 81v-82r: "Insuperbito delle forze sue, prese audacia di contendere con gli Dei, \& d'esserli contrario e molesto, onde Giove consigliandosi sopra ciò con gl'altri Dei, poi diverse sententie gli parve non doverli ruinare, per che mancando il genere humano, non saria chi honorasse gli dei, ne manco gli parve di lasciarli in la sua arrogantia, perche tollerarla sarebbe vituperio alli divini, onde determinò che si dividissero, et mandò Apolline che gli dividesse per mezo a lungo, \& ne facesse di uno due, perche potessino solamente andare dritti per una banda sopra due piedi, \& saria doppio il numero de li divini cultori, ammonendolgli che se piu peccassero contra gli dei, che tornaria à dividere ogni mezo in due, \& restariano con uno ochio, \& una orechia, meza testa $\&$ viso, con una mano, \& un' piè, col quale caminariano saltando come li zoppi, et restarebbeno come gl'huomini dipinti ne le colonne à mezo viso. Il quale Apolline in questo modo li divise, dalla parte del petto, $\&$ del ventre, $\&$ voltogli il viso alla parte tagliata, acciò che vedendo l'incisione si ricordassero del suo errore, \& ancora perche potessero meglio guardare la parte tagliata, \& offesa, sopra l'osso del petto misse cuoio, \& pigliò tutte le bande tagliate del ventre, \& le raccolse insieme, legolle in mezo di quello, il quale ligame si chiama ombelico, circa del quale lasciò alcune rughe fatte dalle cicatrici de l'incisione, acciò che vedendole l'huomo si ricordasse del peccato, \& de la pena. Vedendo ciascuno de li mezi mancare del suo resto desiderando reintegrarse s'approssimava a l'altro suo mezo \& abbracciandosi s'univano strettamente, \& senza mangiare ne bere, si stavano cosi fin'che perivano. Erano i genitali loro alla parte posteriore de le spalle, che prima era anteriore, onde gittando il sperma fuora cadeva in terra, e generava mandragore. Vedendo adunque Giove che il genere humano totalmente periva, mandò Apolline che gli tornasse [i] genitali a la parte anteriore del ventre, mediante li quali uniendosi generavano suo simile, restando satisfatti cercavano le cose necessarie a la conservatione de la vita." [Here and elsewhere for this text, I retain the orthography used in the editio princeps of 1535 , even though in places it is somewhat unusual.] 
From that time forth, love, which heals man's wounds and restores the unity of his primeval nature, was engendered amongst men; and by its restoration of two into one it is the remedy of the sin which led to one being made into two. Love in every man is, therefore, male and female, for each of them is but a half and not a whole man, and therefore desires to be made whole in its other half. 43

Significantly, physical attraction is strictly confined to the perspective of intercourse between men and women, whereas other kinds of sexual orientations are not mentioned.

Hence, in what is characteristic for his cultural and intellectual background, Leone Ebreo describes the primordial humans as exclusively heterosexual pairs, thereby (and even more unambiguously than Ficino) eclipsing any reference to the homosexual or lesbian pairings in Aristophanes' original account. The strategy of avoiding the difficult parts of the speech is simple: according to Leone's reading, the primordial human being was androgynous-male and female-and seems to have existed apart from "single" men and women as we know them.

In the Symposium, in the name of Aristophanes, Plato declares that the beginning of love was on this wise. At the beginning of all things, the human race embraced a third species which was not mere man or woman, but was called androgynous, being at once both male and female.

And as man derives from the sun and woman from the earth, so that kind derived from the moon, which is made up of the sun and earth. An androgyne was thus great, mighty and terrible, having two human bodies joined together at the breast, and two heads on one neck with two faces [...].44

43 Leone Ebreo, The Philosophy of Love, 344-5; Leone Ebreo, Dialoghi d'amore, III, 82r: "Da questo tempo in qua fu generato l'amor' fra gli huomini reconciliatore, e reintegatore de l'antica natura, e quello che torna à fare di due uno remedio del peccato, che fece quando de l'uno fu fatto due, è adunque l'amor' in ciascuno de gl'huomini maschio, \& femmina, però che ogn'uno di loro è mezo huomo \& non huomo intero, onde ogni mezo desia la reintegratione sua con l'altro mezo, [...]."

${ }^{44}$ Leone Ebreo, The Philosophy of Love, 343; Leone Ebreo, Dialoghi d'amore, III, 81r: "[...] Platone [...] dice nel convivio in nome d'Aristofane, che l'origine del' amore fu in questo modo, che essendo nel principio de gli huomini un'altro terzo genere di huomini, cioè non solamente huomini, \& non solamente donne, ma quello che chiamavano Androgeno, il quale era maschio e femmina insieme [...]." Leone Ebreo, The Philosophy of Love, 343; Leone Ebreo, Dialoghi d'amore, III, 81 r-v: "[...] e cosi come l'huomo depende dal Sole, e la donna da la terra, cosi quello dependeva da la Luna participante di Sole, e di Terra, era adunque 
Leone's interpretation, however, does not stop here. According to him, the male and female halves of the primordial being refer to intelligence and body respectively. As will soon become clear, Aristophanes' original tale of double humans is discreetly replaced by an account of androgynous unity, containing male and female aspects alike. Hence, while Plato's original story referred to the relationship between bodies, in the perspective of the Dialoghi Aristophanes' speech explains how intellect and body are related to each other; they are actually matching, or in need of harmonization, which is again in strong contradistinction to Ficino's Christian reading, where the soul is imprisoned or exiled in the body, at least to a certain degree. What is at stake here is the model of a blissful separation of the soul from the body as opposed to the peaceful and harmonious coexistence of both principles. According to Leone Ebreo, sexual intercourse is a means of achieving unity between mind and body, because it was God's intention that the intellect and the body should take care of each other jointly.

[...] Plato says that from this division love was born, because each half desires and loves reintegration with its other half; in other words, the intellect would take no heed of the body save for the love which it bears its consort and female half, nor would the body be governed by the intellect were it not for the love and affection which it bears for its husband and masculine half. Moreover, the story tells us that even when the two halves came together in love they did not seek those things which were necessary for their sustenance, and they perished; wherefore the god Jupiter caused their members of generation to be turned facing each other, and so they remained satisfied and in union and in procreation of their kind their division was healed. 45

In a characteristic move, Leone exploits and at the same time significantly alters or subverts the language of traditional Hellenistic as well as

quello Androgeno grande, forte, e terribile, però che haveva due corpi humani legati ne la parte del petto, e due teste colligate nel collo, un' viso à una parte de le spalle e l'altro a l'altra [...].'"

${ }^{45}$ Leone Ebreo, The Philosophy of Love, 363; Leone Ebreo, Dialoghi d'amore, III, 93r: " $[\ldots]$ dice [Platone] che da questa divisione nacque l'amore, però che ogni mezo desia \& ama la reintegratione del suo mezo restante, cioè che in effetto l'intelletto non haveria mai cura del corpo, se non fusse per l'amore che ha al suo consorte mezo corporeo femminino, ne il corpo si governaria per l'intelletto se non per l'amore \& affettione che ha al suo consorte \& mezo masculino, \& in quello che dice uniendosi l'un'mezo con l'altro, per l'amore non cercavano le cose necessarie per il sostenimento loro \& perivano; onde per remedio Iuppiter li fece tornare li genitali de l'uno verso de l'altro, \& satisfatti per il coito \& generatione del simile si reintegrò la loro divisione, [...]." 
Christian body-discourses: according to the Peripatetic tradition, it was female matter that loved male intellectual forms, but, as Aristotle points out, this affection was not reciprocal (Physics I, 9 192a 20). In Ficino's account, Aristophanes' tale was read as a purely psychological drama between the higher and lower parts of the soul, the body remaining completely left out. In Leone's Dialoghi, instead, the story relates to a reciprocal relationship between mind and body within a single human being. Like Ficino before him, Leone concludes by saying that his interpretation of Aristophanes' tale is exhaustive and that the rest of the Platonic story is merely ornament (hence, one may conclude that he was well aware that he had left out certain important details, that is, the part where Aristophanes states that heterosexual men and women descending from the mixed race of androgynes, produce the highest number of adulterers (191E). 47

This is the allegorical meaning of the Platonic myth, and the other details concerning the actual incision, the council of the gods and such like, are but ornaments of the story to make it more pleasing and lifelike in its form. 48

In what has been said so far, Leone's reading of Aristophanes' story differs from that of Ficino on several crucial issues: the positive assessment of heterosexual relationships, rather than its derision, as well as the appraisal of the mutual love between intellect and body, which in order to be saved should strive for union rather than for separation. In that context, Leone claims the textual authority of the Jewish tradition by maintaining that Plato is in fact repeating a key story from Genesis and that the philosopher presents Moses' words in the loquacious and disorderly way characteristic of the Greeks. ${ }^{49}$

${ }^{46}$ In a similar vein, Ficino had regarded the body as a well designed trap to lure souls down from heaven and trap them.

47Plato, Opera omnia, 1602, 1186 D: “[...] quamobrem quicumque ex viris promiscui generis portio sunt, quod olim androgynum vocabatur, ex his reperiuntur, Ex hoc sane genere moechi ducunt originem."

48 Leone Ebreo, The Philosophy of Love, 364; Leone Ebreo, Dialoghi d'amore, III, 93 v: "Questo è quello che significa la favola Platonica allegoricamente, \& l'altre particularità che scrive nel modo del dividere, e del consultare \& simili sonno ornamenti de la favola, per farla piu bella \& verisimile."

${ }^{49}$ The ornate Greek style was censured in many of the Latin textbooks of rhetoric which were formative for many Renaissance humanists. See, for instance, Cicero, De oratore II, 17-20, and I, 102: "[... tamquam alicui graeculo otioso et loquaci et fortasse docto atque erudito quaestiunculam, de qua meo arbitrio loquar [...]." 
Moses did not tell the story so plainly, nor in such detail, but the substance of the story he told briefly; it was from him that Plato took his myth, amplifying and polishing it after the manner of Greek oratory, thus giving a new and confused account of the Hebrew version. 50

This stratagem allows Leone to wrestle with the authority of the Greek as well as the Christian tradition: What follows is a (talmudic) reading of Genesis 1, 26-27.51 In the ensuing comparison of Aristophanes to the biblical text (but also in many other instances), Leone stresses that even God has male and female aspects, and that Adam, the first man, was created in his likeness, male and female, that is, androgynous, an idea that is repeated several times in the Dialoghi.

God created Adam (that is man) in his own image, in the image of God created he him; male and female created he them.)

This is the book of the generation of Adam. In the day that God created man, in the likeness of God made he him; male and female created he them; and blessed them, and called their name Adam (that is man), in the day when they were created.

The first man, and indeed every other human being in the whole wide world, is made, as Scripture testifies, in the image and likeness of God, both male and female at once. 52

The idea that the primordial human was androgynous allows Leone to maintain that the separation of the double humans in the Platonic story actually refers to the creation of Eve in Genesis, from Adam's side, and not merely from his rib.

${ }^{50}$ Leone Ebreo, The Philosophy of Love, 345; Leone Ebreo, Dialoghi d'amore, III, $82 \mathrm{v}$ : "Non l' ha già favoleggiata [Moise] con questa particularità e chiareza, ma ha posta la sustantia de la favola sotto brevità, e Platone la prese da lui, \& l'ampliò, \& ornò secondo l'oratoria grecale, facendo in questo una mescolanza inordinata de le cose hebraic[h]e."

51 See also Yavneh, "The Spiritual Eroticism," 88, for a reference to the Zohar.

52 Leone Ebreo, The Philosophy of Love, 346; Leone Ebreo, Dialoghi d'amore, III, 82v: "Creo Dio Adam cioè l'huomo in sua forma, in forma di Dio, creò esso maschio e femmina, creo essi [...]." Leone Ebreo, The Philosophy of Love, 3467; Leone Ebreo, Dialoghi d'amore, III, 83r-v: "Questo è il libro de la generatione di Adam nel di che Dio creò l'huomo in somiglianza di Dio, fece esso maschio e femmina, gli creò \& gli benedisse, \& chiamò il nome loro Adam, cioè huomo nel di che furono creati." Leone Ebreo, The Philosophy of Love, 354; Leone Ebreo, Dialoghi d'amore, III, 87v: "PHI.: Il primo huomo, \& ogn' altro huomo di quanti ne vedi è fatto come dice la scrittura, a immagine, \& similitudine di Dio, maschio e fermmina." 
[...] taking one of Adam's ribs from him in sleep. The woman, therefore, was not made in the beginning, as was first said. Again, at the end of the narrative, speaking of the offspring of Adam (as you have seen), we read that God created man in the likeness of God, male and female created $\mathrm{He}$ them, and He called their name Adam in the day that they were created. It would appear, therefore, that there was at once both male and female at the beginning of the Creation, and that (the woman) was not made subsequently by the withdrawal of the side or rib as is narrated.)

[...] took one of his sides, the word in Hebrew being equivalent to rib, but here and elsewhere it stands for side, that is, the side or feminine person [....$^{53}$

The contradiction in the sacred text-Moses first speaks of Adam in the singular and then in the plural-encourages the thoughtful reader to realize that divine mysteries are hidden in the text.

[...] it is inconceivable that the divine Moses should contradict himself so obviously as to seem deliberately. Hence it is credible that he wished to infer a hidden mystery beneath these obvious discrepancies. ${ }^{54}$

The evidence that primordial man was androgynous is further substantiated by the Hebraic commentary traditions:

[Moses] wants to say that Adam, that is the first man, whom God created on the sixth day of the Creation, being a human individual, combined in himself male and female without division; and therefore the text says that God created Adam in his Own likeness, [...]. Wherefore the ancient Hebrew commentators in their Chaldean commentary here say, 'Adam was created of two persons, the one part male the other female.' 55

53Leone Ebreo, The Philosophy of Love, 347; Leone Ebreo, Dialoghi d'amore, III, $83 \mathrm{v}$ : "[...] fece dormendo [... Adam] d'uno dei suoi lati, non era adunque fatta nel principio come havea detto ancora nel fine volendo narrare la progenie di Adam dice (come hai veduto) che Dio gli creò in somiglianza di Dio maschio, e femmina, creò quegli, \& chiamo il nome loro Adam, nel di che furono creati; Adunque pare che nel principio de la creatione sua di continente fussero maschio, \& femmina, \& non di poi per sottratione del lato, o costa, come ha detto [...]." Leone Ebreo, The Philosophy of Love, 349; Leone Ebreo, Dialoghi d'amore, III, 85 r: "[...] pigliò uno de li suoi lati, il quale in hebraico è vocabolo equivoco a costella, ma qui et in altre parti ancora sta per lato, cioè il lato, o persona femminile [...]."

${ }^{54}$ Leone Ebreo, The Philosophy of Love, 348; Leone Ebreo, Dialoghi d'amore, III, 84r: "[...] non è da credere ch'el Santo Moise si contradica cosi manifestamente che par'che egli procuri contradirsi. Onde è da credere che vogli inferire qualche occulto misterio sotto la manifesta contraditione."

55Leone Ebreo, The Philosophy of Love, 348-9; Leone Ebreo, Dialoghi d'amore, III, 84v: "Vuol dire che Adam cioè huomo primo, il qual Dio creò nel di sesto de la 
By referring rather casually to linguistic details that were difficult for non-Jews to grasp, as well as to a body of commentaries inaccessible to Christians, Leone establishes Mosaic authority over the biblical text and over the Platonic tradition. No wonder he has Sofia saying approvingly: "It is indeed pleasing to learn that Plato drank of the waters of the sacred font." 56 This appropriation of Aristophanes' myth in the Dialoghi has an important consequence: in contrast to Ficino, for whom Diotima's speech was of key importance while the story of the double humans was somewhat secondary, Leone emphasizes its fundamental role in the understanding of what humans are because it outlines the entire story of the human race.

All these things the first man really suffered in his body; and they are symbolic of the life and works of every man, his ultimate happiness, the demands of his corporeal nature, and the consequences of excessive sin together with its punishment and the possibility of eventual salvation. If you look into the story, you will behold as in a mirror the life of every man with his good and his evil, and you will recognize the way which must be shunned and the way which must be followed to attain to eternal happiness where there is no death. ${ }^{57}$

Consequently, Aristophanes' myth serves Leone as a pretext to develop a type of anthropology that reflects his Jewish background. The androgynous primordial human, Adam, was a harmonious unity of body and mind who did not feel any inclination to sin. Thus, Leone concludes that the intentions of Plato and Moses were the same, even if their ways of telling the story were different. In Leone Ebreo's anthropology the original double humans are first reduced to a heterosexual pairing which then becomes related to a division in mind and body in the first human being.

creatione essendo un'supposto humano conteneva in se maschio, \& femmina senza divisione, \& però dice che Dio creò Adam ad immagine di Dio $[\ldots]$ però commentano qui li commentarij Hebraici antichi in lingua caldea dicendo, Adam di due persone fu creato d'una parte maschio, da l'altra femmina [...]." ${ }^{56}$ Leone Ebreo, The Philosophy of Love, 350; Leone Ebreo, Dialoghi d'amore, III, $85 \mathrm{v}$ : "Mi piace vedere che Platone habbi bevuto de l'acqua del sacro fonte [...]." 57Leone Ebreo, The Philosophy of Love, 361-2; Leone Ebreo, Dialoghi d'amore, III, $92 \mathrm{r}$ : "[...] le quali cose intervenne in effetto corporalmente al primo huomo, denotano (secondo l'allegorico) le vite, \& successi di ciascuno de gl'huomini; Qual' sia il fine loro beato, ciò che richiede la necessità de l'humanità, 8 il successo del eccessivo peccato, \& la pena de l'accidente di quello, con l'ultima possibilità del remedio, se ben'l intenderai in uno specchio vedrai la vita di tutti gl'huomini, il loro bene \& male, conoscerai la via che si debbe fuggire, \& quella che si debbe seguire per venire a eterna beatitudine senza mai morire." 
Notably, Plato does not speak of a hermaphrodite, but rather of double humans: "[...] man and woman, $[\ldots]$ come together again as one body and individual in marriage and sexual intercourse." 58 Contrary to Ficino's position, sexual intercourse and procreation are a remedy for sin: it is a sacred union that is performed by humans to regain temporarily their divine unity once again. According to Leone, to sin means to turn away from the body and neglect the duties that mind and body owe each other. (Moreover, after the Fall, sex is the only means to perpetuate the species.)

[...] generation, as Aristotle says, was a remedy for mortality. Therefore man, as long as immortal, did not procreate his kind; but when through sin he was made mortal, he came to his own aid by raising up his like, which power God had bestowed potentially upon him, so that by one means or another the human race should not perish. ${ }^{59}$

By interpreting a quotation from Aristotle, Leone again discreetly subverts the original myth according to which sexuality is not viewed primarily as a means to create offspring but rather as an urge to reestablish a primordial unity (at least temporarily) in order to maintain one's own psycho-physical equilibrium. As in Ficino, there is a connection between sin and separation; yet in the perspective of the Dialoghi, that nexus does not result in a division between higher and lower parts of the soul, but instead in the separation of male minds and female bodies in one and the same individual.

Sin is truly that which causes division in man and cuts his nature in twain, just as righteousness makes a man to be single and preserves the unity of his nature. Again, we can truly say that division in man produces sin, for in so far as he is single, he has no inclination to do evil nor to impair his union. Therefore since sin and division in man are almost the same thing, or at least two inseparable things, the one always implying the other, sin may be said to spring from division-according to the version of the Scriptures-and division from sin-according to Plato. ${ }^{60}$

${ }^{58}$ Leone Ebreo, The Philosophy of Love, 350; Leone Ebreo, Dialoghi d'amore, III, $85 \mathrm{r}$ : "[...] l'huomo e la donna si tornano à reintegrare nel matrimonio, \& coito in uno medesimo supposto carnale, $\&$ individuale [...]."

${ }^{59}$ Leone Ebreo, The Philosophy of Love, 354; Leone Ebreo, Dialoghi d'amore, III, 87v: "La generatione (come dice Aristotile) fu per remedio de la mortalità, \& però l'huomo in quanto fu immortale non generò, quando già per il peccato fu fatto mortale si soccorse con la generatione del simile, alla quale Dio li diede potentia accioche o a un'modo, o a un'altro non perisca l'humana spetie."

${ }^{60}$ Leone Ebreo, The Philosophy of Love, 351; Leone Ebreo, Dialoghi d'amore, III, $85 \mathrm{v}$ : "In effetto il peccato è quello che incide l'huomo e causa in lui divisione, cosi come la giusta dritteza il fa uno, \& conserva la sua unione, $\&$ anchora pos- 
The identification of sin and division is tied to the biblical story of the Fall, that is, it is related to a theological context in a rather arbitrary way. And, of course, according to the Symposium the separation of the primordial human beings occurs in order to weaken humans and to prevent them from sinning (e.g. plotting) against the gods. (If one cannot speak of the concept of sin in Aristophanes' perspective, then in the political context of a coup d'etat against the gods.) In the Dialoghi, on the other hand, the connection of the myth of the androgyne with theology is much closer than in the commentary of Ficino, who perhaps deliberately sought to avoid too close an association of Aristophanes' speech with Christian doctrine.

Leone also briefly discusses the idea that the story in itself is only allegorical, that is, that the primordial hermaphrodite never existed in flesh and blood. Hence, the myth indicates that men and women before the Fall did not feel the urge to have sex because they were busy contemplating God, which is mankind's true purpose in life and is brought about by a harmonious proportion between the male and female aspects of the individual.

SO.: [...] For I do not believe that man and woman were at any time other than divided into two bodies [...]. PHI.: [...] to denote union not of the flesh, but of human essence and intellectual inclination, that is, they were united in blessed contemplation of the Divinity, not in sexual intercourse and carnal delights, but in order that they might be of greater assistance to one another. ${ }^{61}$

Finally, the idea of a merely allegorical reading of that passage is dismissed because God created the first humans (even while they were in paradise) in a way that they did not exclusively worship the intellectual aspects of the divinity, but also looked after their bodies (hence, obviously, desire did not cause the Fall and sex is not sinful). God created their intellect in such a form that it felt inclined towards the necessary physical desires.

siamo dire con verità, che essere l'huomo diviso il fa peccare, che in quanto è unito non ha inclinatione a peccare, ne à divertirsi da la sua unione, di modo che per essere il peccato, e la divisione de l'huomo quasi una medesima cosa, o due inseparabili e convertibili, si puo dire che da la divisione viene il peccato (come dice la sacra scrittura) e dal peccato viene la divisione (come dice Platone)."

${ }^{61}$ Leone Ebreo, The Philosophy of Love, 352-3; Leone Ebreo, Dialoghi d'amore, III, 86v-87r: "SO.: [...] che non crede già che l'huomo e la donna in alcun' tempo fussero altrimenti che in due corpi divisi, [...]. PHI.: [...] non che fussero uniti corporalmente, ma uniti in essentia humana, et inclinatione mentale, cioè tutti due alla beata contemplatione divina, \& non l'uno a l'altro per diletto e coito carnale, ma perche meglio l'uno a l' altro si potessi aiutare." 
And the Divinity could foresee that this life of union of the two parts of man, and of the obedience of the feminine body to the masculine intellect, although it brought happiness to the man and immortality to his essence, which is his intellect, it rather corrupted his bodily and feminine part. And not only is this true of the individual, for when the intellect is inflamed with the knowledge and love of the eternal and divine it abandons all care of the body and leaves it to perish before its time, but also of the preservation of the human race; for those who are wedded to a life of intellectual contemplation despise corporeal love and flee from the lascivious act of generation, and this intellectual perfection would cause the human race to become extinct. Therefore God determined to establish some division or means between the feminine sensual part and the masculine intellectual part, turning the senses and the intellect to certain corporeal desires and activities necessary for the sustenance of the individual man for the preservation of the species. ${ }^{62}$

So, even in its purest state the human intellect enters into a relationship with body: Leone speaks of the possible dangers of exaggerated intellectual contemplation, a topic not uncommon to Jewish discursive forma-

62 Leone Ebreo, The Philosophy of Love, 356; Leone Ebreo, Dialoghi d'amore, III, 88v-89r: "[...] pur' preconoscendo la divinità che questa via d'unione de le due parti de l'huomo e dell' obedientia de la corporea femminina alla intellettuale masculina, se bene felicitava l'huomo, \& faceva immortale, l'essentia sua che è sua anima intellettiva faceva piu presto corrompere la parte sua corporea e femminina, cosi nel individuo, però che quando l'intelletto s'infiamma ne la cognitione, e amore de le cose eterne e divine abbandona la cura del corpo, \& lasciala anzi tempo perire, come ancora ne la successione de la spetie humana, perche quelli che sono ardenti alle contemplationi intellettuali sprezano gl'amori corporei, \& fuggono il lascivo atto de la generatione. Onde questa intellettual' perfettione causaria perditione de la spetie humana; Per tanto Dio deliberò porre qualche divisione temperata frà la parte femminina sensuale, e la parte masculina intellettuale, tirando la sensualità, l'intelletto a alcuni desiderij, \& atti corporei necessarij per la sostentatione corporea individuale, \& per la successione de la spetie." It is interesting to note how in his Commento Pico (De hominis dignitate III, 4: 528) endorses a totally different interpretation with almost the same words: here the body is again conceptualized as a temporary prison for soul, not as its necessary complement. "Similmente, se convertono gli occhi verso l'intelletto, non possono provvedere più al corpo ed è necessario che lascino la cura di quello; e per questa ragione queste anime, alle quali è forza per la cura del corpo lasciare el bene dello intelletto, la provvidenza divina la ha legate a corpi caduci e corruttibili, da' quali solute in breve tempo possino, [...] alla loro intellettuale felicità ritornare; [...]." On possible connexions between Pico and Leone Ebreo, see Veltri, "Philo and Sophia." 
tions. ${ }^{63}$ It is interesting to note that this idea is repeated in a different context when Filone in the Dialoghi says that the philosophies of Plato and Aristotle were complementary, as the former was primarily concerned with the soul, whereas the latter was more interested in the body. Both philosophers actually addressed contemporary ethical problems, as Plato was attacking his materialist predecessors so successfully that people stopped caring for the body, a negligence against which Aristotle's natural philosophy worked as an antidote. 64

The idea that love is born from the division of the intellect from the body is, of course, in sharp contrast to Neoplatonic concepts as well as, to a certain extent, to Plato's philosophy, because the love for corporeal beauty induces the onlooker to separate the body from the form of beauty.

[...] all human love and desire is born of the coalternate division of the human intellect and body, because the intellect inclined to its body, like the male to the female, desires and loves the things which belong to it, and if these objects are requisite and temperate, virtuously, on account of their moderation and restraint, and if they are excessive, then with lascivious and corrupt affections leading to sinful actions. Again the body, loving the soul as the woman the husband and male, rouses herself to desire his perfection, striving with sense, eyes and ears, and with the [inner] sense of imagination and memory, to obtain what is necessary for right thinking and eternal intellectual treasure in which the mind of man is blessed. And this desire and love is absolutely virtuous, and the more ardent it is, the more praiseworthy and perfect. ${ }^{65}$

So, again, the trouble does not arise from soul or intellect becoming too close to the corporeal natural world, but from the separation of mind

63 Boyarin, Carnal Israel, 134-166.

${ }^{64}$ Leone Ebreo, Dialoghi d'amore, III, 116v-117r.

${ }^{65}$ Leone Ebreo, The Philosophy of Love, 364-5; Leone Ebreo, Dialoghi d'amore, III, 93v-94r: "[...] che tutti gl'amori e desiderij humani nascono da la coalternata divisione dell'intelletto, e corpo humano, però che l'intelletto inclinato al corpo suo (come il maschio alla femmina) desia $\&$ ama le cose pertinenti à quello, \& se sonno necessarie \& moderate, sonno desiderij, \& amori honesti per la loro moderatione \& temperamento, \& se sonno superflui, sonno lascivi, \& dishoneste inclinationi e atti peccatorij; Ancora il corpo amando l'intelletto (come don[n]a il marito maschio) si solleva in desiare le perfetrioni di quello sollecitando con li sentimenti, con li occhi, con le orecchie, \& col senso, fantasia et memoria, d'acquistare il necessario per le rette cognitioni, \& eterni habiti intellettuali, con che si felicita l'intelletto humano, \& questi sonno desiderij, et amori assolutamente honesti, et quanto piu ardenti tanto piu laudabili, [...]." 
and body. In this way Leone completely overturns not only Plato's anthropology but also Ficino's.

An interesting question arises on the extent to which Leone's reading was consciously directed against Ficino's Christian interpretation. There is at least some internal textual evidence that Leone was aware of, and hardly sympathetic to, Ficino's commentary. Although he does not mention the De amore directly, he refers in great detail to a passage of Ficino's commentary. In this case Leone makes decidedly critical remarks about the exaggerated allegorical reading of Diotima's myth of the birth of love, a criticism that could equally apply to Ficino's elaborate psychological interpreration of Aristophanes' primordial humans. ${ }^{66}$

Some there are who understand by the birth of Venus the influence of the intelligence, first in the angelic world and then in the soul of the world, life already having been imparted by Jupiter, essence by Saturn, and first being by Caelus, who were the three Gods at the feast before the birth of the greater Venus in the angelic and lower world and in the world soul. But we take no heed of such abstract and endless, indisproportionate allegories which do not correspond to the letter of the story. ${ }^{67}$

Compare this to the following passage in Ficino's Symposium commentary

On the birthday of Venus, that is, when the Angelic Mind and the World Soul (which we call Venuses, for the reason which we have given elsewhere) were born from the supreme majesty of God. While the gods were feasting, that is, while Uranus, Saturn, and Jupiter were enjoying their respective powers. For at the time when the intelligence in the Angel and the power of procreating on the World Soul, powers which we rightly call twin Venuses, first came into being, the supreme God, whom they call Uranus, was already in existence; moreover, existence and life, which we call Saturn and Jupiter, already existed in the Angelic Mind, and also in the World soul there already existed the knowledge of the superior things

66 See Boyarin, Carnal Israel, 8, on the connections between anthropology and hermeneutics in both Christian and Jewish discursive formations.

67Leone Ebreo, The Philosophy of Love, 368-9; Leone Ebreo, Dialoghi d'amore, III, 95v: "Sonno alcuni che dicono intendersi per la natività di Venere l'influentia dell'intelligentia dell'Angelo prima, \& poi nell'anima del' Mondo, havendo già participato la vita di Giove l'essentia di Saturno, \& il primo essere di Celio, che erano li tre Dei del convito precedente a la natività di Venere magna, ne l'Angelo, \& ne la mondana, \& nell' Anima del'Mondo. Ma noi non curaremo d'allegorie si astratte, \& interminate, \& improportionate al litterale fabuloso." 
and the moving of the celestial bodies, which powers, again, we call Saturn and Jupiter. ${ }^{68}$

There is more to this controversy than the (fairly obvious) observation that Leone is making a critical remark against Ficino's interpretation and that he therefore must have read at least parts of the commentary on the Symposium. Leone's refutation of "abstract and endless, indisproportionate allegories" refers to a deep rift between rabbinic Judaism and Christianity that recently has been brilliantly discussed by Boyarin. In his Tractatus adversus Judaeos Augustine had accused the Jewish people of being the representatives of "Israel in the flesh" as opposed to the Pauline "spiritual Israel", or believers in Christ (Jews and non-Jews alike). Related to this initial and fundamental distinction, Augustine accused the Jewish tradition of being unable to see that external realities (bodies) have spiritual significance, and therefore of misunderstanding the real meaning of Scripture. Boyarin says that:

[...] whereas Augustine consigns the Jews to eternal carnality, he draws a direct connection between anthropology and hermeneutics. Because the Jews reject reading 'in the spirit,' therefore they are condemned to remain 'Israel in the flesh.' Allegory is thus, in his theory, a mode of relating to the body. 69

Thus, much more than just accusing a Christian philosopher of using the wrong interpretative strategies, Leone's brief remark refers to the core of the deep antagonism separating the two cultures, rifts which become obvious in the different discourses which are transformed into conflicting interpretative strategies regarding the body. From Leone's point of view, it

${ }^{68}$ Ficino, Commentary on Plato's Symposium, 116; Ficino, Commentaire sur le Banquet, VI, 7: 208-209: "In Veneris natalibus, id est, quando mens angeli et mundi anima, quas veneres ea ratione quam alias diximus nominamus, ex summa dei maiestate oriebantur. Diis discumbebant, id est, Celus, Saturnus, Iupiter bonis propriis vescebantur. Nam cum in angelo intelligentia et in mundi anima vis generandi, quas proprie veneres geminas apellamus, prodibant in lucem, iam erat summus ille deus quem vocant Celum; essentia preterea et vita in angelo, quos Saturnum vocamus et lovem, atque etiam in mundi anima inerat supernorum cognitio et celestium corporum agitatio, quos iterum Saturnum lovemque vocamus." It is interesting to compare this passage again to Pico, De hominis dignitate III, 1: 521-522, which repeats Ficino's text and hence also may have been a target for Leone Ebreo's criticisms. See also ibid. 2. 13: 501-504.

${ }^{69}$ Boyarin, Carnal Israel, 8. For a discussion of this entire complex of ideas, relating to Paul, Augustine, Origen and Philo, ibid., 1-10. 
is wrong to allegorize too much the myth of the birth of Eros, because it is foreign to an important part of his own interpretative tradition. Midrash, the hermeneutic system of rabbinic Judaism, refutes the Platonic-Christian dualism of body and soul thus "eschewing the inner-outer, visible-invisible body-soul dichotonomies of allegorical reading. Midrash and platonic allegory are alternate techniques of the body." 70

Leone Ebreo's reading thus differs in many important respects from Ficino's interpretation of Aristophanes' speech. In contrast to Ficino, whose reading Leone appears to have been less than sympathetic to, the reading of the Dialoghi does not eclipse the body and the female aspect of creation. As in Plato, desire is fulfilled in the sexual act, at least temporarily. Physical love (seen as a yearning for original unity) incorporates in the Dialoghi a kind of redemptive power. The desire for the reintegration of male and female fits well into Leone's theology, in which the entire creation is to be united to the godhead. ${ }^{71}$ In fact, "physical union is presented as a manifestation of a higher spiritual union; as such, it is not to be denied, but rather celebrated." 72 Whereas Ficino's reading precludes the amorous conversation between men and women, the Dialoghi are entirely dedicated to that topic. In that sense Leone's interpretation is perhaps more appealing to modern readers than Ficino's version of a merely spiritual friendship between men, though with one important qualification: it remains impossible for Leone to acknowledge even the existence of any sort of homosexual love, as Ficino did.

Leone Ebreo's structural difficulties become apparent when he tries to read one myth (Aristophanes) through another (Moses on Creation) or wants both myths in their more or less allegorical interpretations to coincide: hence the argument of the Dialoghi does not rest so much on reasoned arguments as on the superiority of the Mosaic tradition. Ficino, on

${ }^{70}$ Boyarin, Carnal Israel, 9.

${ }^{71}$ Leone Ebreo, Dialoghi d'amore, III, 129v: "SO.: È adunque l'amoroso matrimonio de l'huomo, e de la donna simulacro del sacro \& divino matrimonio del sommo bello, \& la somma belleza, di che tutto l'universo proviene, se non che è differentia ne la somma belleza, che non solamente è mogliere del sommo bello, ma prima figliuola prodotta da lui. PHI.: Ancora in questo vedrai il simulacro nel primo matrimonio humano, che Eva prima fu cavata di Adam come padre, \& figlia sua, \& poi gli fu mogliere in matrimonio, di tutto questo discorso credo che debbi suffitientemente conoscere come l'amore de l'universo nacque de la prima belleza come di padre, \& de la cognitione che ha di lei la prima intelligentia creata motrice del sommo orbe che tutto l'universo corporeo contiene [...]."

72 Yavneh, "The Spiritual Eroticism," 87. 
the other hand, sought to apply another sort of hermeneutics to his Neoplatonising psychological interpretation and tried to avoid any references to Christian theology.

In that respect, the price of Leone's assimilation of Aristophanes' myth to the Jewish discursive formation is high indeed: Plato is not an ancient author to be studied for his own sake, but merely the more or less confusing imitator of the source of sources, the Torah. In that sense, Ficino's approach is more open to the study of the classical heritage, which he tends to see as texts on an equal level with other sources of revelation. The common link between these two philosophical anthropologies, that of Leone Ebreo and that of Marsilio Ficino, is that they are to a notable extent rooted in their respective theologies and present a conceptualization which remains highly debatable in the case of the original setting of Aristophanes' story. Far from aiming at divine allegories of higher truths, the Athenian comedian had of course referred, however satirically, to the social and political context of the Athenian state, to the political bodies and sexual inclinations of real men and women, rather than to obscure divine mysteries. It seems that Giordano Bruno considered and understood this aspect of the story of the double humans better.

\section{Bruno: The Convertibility of Eros into Money}

The third and last work under consideration is not a philosophical treatise in the proper sense: Giordano Bruno's comedy Il Candelaio (The Candlebearer, 1582) can be read as a concise account of the ubiquitous metamorphoses of sexual desire and its convertibility into money. Accordingly, the play is populated by lechers of all sorts, pedophiles, homosexuals, and luckless alchemists, all of whom are examples of the universal drive for physical fulfillment. In this satire on the Renaissance Neoplatonic philosophy of love, the candela or candle functions as an obscene metaphor for the penis and at the same time as an allegory for the illumination of the mind. In a play that Moliterno has aptly described as "a microcosm of the degraded ideals of Renaissance culture as a whole," 73 we find a final, distant, but nevertheless very comical, echo of Aristophanes' myth, whose the significance was completely reversed by Bruno.

The context of the appearance of the double humans is the following: Bartolomeo's sexual life is misled by his hunger for money, which is why he has started to neglect his wife and spends his time instead in an alchem-

${ }^{73}$ Moliterno in Bruno, Candlebearer, 29. 
ical laboratory. He entrusts all his funds to an impostor, who, before disappearing with the money, collaborates with a corrupt apothecary, Consalvo. When the latter meets Bartolomeo, the two men instantly engage in a vicious debate:

CONSALVO: I had words with him and we came to blows. Certain scoundrels dressed up as the night watch came running at the noise and tied us up [...]. they changed us around and tied us, hands behind our backs and bum to bum as you see us. First they took our purses and went off; then, remembering something, two of them returned and took our mantles and our berets and they sliced our shirt open with a razor. Then we wandered about and argued $[\ldots]$ as I tried to pull this good fellow along $[\ldots] .7^{74}$

This strange couple is, of course, a perfect caricature of Aristophanes' primordial humans: both are united by the same desire (though for money and not for sexual union) and instead of loving each other they "came to blows." Being tied together, they are not at all strong or frightening, but deprived of all their belongings and hardly able to move:

CONSALVO: Let's get up. May you never get up again, either now nor ever! $[\ldots]$

BARTOLOMEO: You peasant cuckold.

CONSALVO: You are biting now, are you? I swear by Saint Cuckoofat that if you want to play at biting, I'll rip your nose from your face and wrench your ears from your head. ${ }^{75}$

Aristophanes had assigned the double males the most important role in public life, whereas the luckless couple in the Candelaio perceive their vulnerable state as a source of embarrassment and public shame: "Let's get up, pig; it will be even more embarrassing if they find us like this." 76 Also

${ }^{74}$ Bruno, Candlebearer, 161; Bruno, Candelaio, V, 13: 107r-v: "Consalvo: Io havevo paroli con costui. siamo venuti a pugni. Corsero certi marioli in fazzone di birri al rumore, ne legorno $[\ldots]$ ne svoltorno l'altre mani a dietro in questa forma che vedete, à culo à culo. \& per la prima ne levorno le borse \& si partirno: poi ricordatosi meglio, ritornorno dui di essi; \& ne levorno, i mantelli \& le berrette, $\&$ ne hanno scuciti gli panni di sopra con un rasoio, dopo siamo noi partiti, \& habbiamo discorso [...] \& al tirar che feci di questo buon huomo"

${ }^{75}$ Bruno, Candlebearer, 160; Bruno, Candelaio, V, 12: 106r: "Consalvo: Alziamoci che non possi alzarti né mo', ne mai. [...] Bartolomeo: Cornuto coteconaccio fuuuh. Consalvo: Oimè mi mordi, anh? Giuro per $\mathrm{S}$. Cuccufatto: che si tu vuoi giocare a mordere, ti strepparrò il naso di faccia, ò ver un'orecchia di testa."

76 Bruno, Candlebearer, 160; Bruno, Candelaio, V, 13: 106v: "Consalvo: Alziamoci porco; sarremo peggio svergognati si sarremo trovati cossi." 
there is not even a trace left of the ability to move (let alone to conquer mount Olympus) and one can hardly imagine that the two men would wish Hephaestus would join them together.

\section{Consalvo: [...] Don't you want to get up?}

BARTOLOMEO: I told you that I want to remain here like this for the whole night. [...]

CONSAlvo: [...] as I tried to pull, he fell like an overloaded donkey and he brought me down with him; and then, out of spite, he wouldn't get up. ${ }^{77}$

At first sight, to a passer-by, these double humans seem to be just drunkards, ("Hey, there, you drunkards. What's the matter?"78) who have to be separated and sent in opposite directions, so as not to start quarrelling again. "Don't start beating each other again because the first one to move will have two against him." 79 Their manner of saying goodbye again emphasizes the complete reversal of Aristophanes' tale: instead of longing to be united again, they simply hate each other: "Hope to see you again in a hundred years." 80

Though Bruno admittedly does not give any direct evidence that he is referring to Aristophanes' tale, it nevertheless has to be emphasized that unacknowledged parody and irreverent travesty of Plato's venerable dialogues are a common feature of Bruno's writings. ${ }^{81}$ It is perhaps no coincidence that the Paduan philosopher Marcantonio Genua (or Passeri) (1490/1-1563) had a medal cast with two engraved humans who are welded together at their backs struggling to make their way: the inscription makes Bruno's irony even more acrimonious "Philosophia duce regredimur" (With philosophy taking the lead we will get back). 82

77 Bruno, Candlebearer, 161; Bruno, Candelaio, V, 13: 106v: "Consalvo: [...] Non ti voi alzare? Bartolomeo: Io ti ho detto che voglio dimorar tutta questa notte cossi." Ibid. 107v: "[...] Consalvo: Al tirar che feci di costui: cascò come un asino che porta troppo gran soma: $\&$ ha fatto cascar anchora me, $\&$ per perfidia non si vuole alzare."

${ }^{78}$ Bruno, Candlebearer, 161; Bruno, Candelaio, V, 13: 107r: "Scaramuré: [...] Olà, imbreachi? che havete, che fate cossi llà?"

79 Bruno, Candlebearer, 162; Bruno, Candelaio, V, 13: 108r: "Scaramuré: [...] Guardate di battervi: perche il primo di voi che si mouverà; ne harrà dui contra."

${ }^{80}$ Bruno, Candlebearer, 162; Bruno, Candelaio, V, 13: 108r: "Consalvo: A'rivederci da ora a cent'anni."

${ }^{81}$ Compare for example Bruno, Candelaio, V, 9-10: 98r-101r with Cratylus 431b$442 \mathrm{a}$.

${ }^{82}$ On this medal, see Wind, Pagan Mysteries, 201-202 with n. 40 and fig. 67, 68. 
Moreover, it is crucial to observe that the Candelaio realigns the myth of the primordial human beings with the politics of power. Neither Consalvo nor Bartolomeo are hiding divine truths; they are disunited by their greed for money, that is, by their desire to act in society. Thus, although for Bruno the Symposium has lost its authority as a source of divine revelation (so assiduously elaborated and contested by generations of Renaissance intellectuals), the Candelaio nevertheless brings back some of the original irony and the political background of Aristophanes' speech. ${ }^{83}$ Bruno is not only aware of the satirical and comical mood of the original text; by overturning the content of the myth, he also forges a new work, which is intentionally only a distant echo of Plato's original intentions. ${ }^{84}$ In that sense, the Candelaio opens new perspectives for future generations to read the Symposium as a literary resource in the spirit of Aristophanes rather than in the mood of Plato, thus again directing the reader's attention away from a more or less linear commentary back to the literary and dramatic setting of a text, the mise en scène of supposedly abstract thought. 85

\section{Universität Wien, Vienna, Austria}

83 Moreover, Bruno does not seem to regard homosexuality as repulsive or against nature: this becomes obvious as the main character of the play, Bonifacio ('the candelaio' or candelbearer) is originally homosexual and becomes, much to his detriment, a womanizer.

${ }^{84}$ A quotarion from Cavell, Disowning Knowledge, 24-25, concerning the relationship between texts is to the point: "Whatever an earlier play called something like King Lear contains, its translation into Shakespeare's medium is inherently predictable; and however interesting the comparison may be in certain cases, it cannot determine what is going on in the Shakespeare. A complementary relation is that between a work of Shakespeare and certain spectaculars or panoramas "based upon" that work. In that case you might call Shakespeare's text not a treasure but a sea, from which various items-treasures, corpses, shells, weeds, more or less at will-were lifted and heaped on the shore of big entertainment."

85 Attention among classical philologists to the literary setting of Plato's works has been growing over the past decades; see, for example, Nussbaum, The Fragility of Goodness, 227: "Plato tells us that we cannot throw away the images and the drama as delightful decorations, or lift out his arguments from the "literary" context for isolated dissection. Still less we can abandon the arguments or relax the demands of our critical faculties. The whole thing is a music discourse, which asks us the full participation of all parts of our souls." Nussbaum, Love's Knowledge, 15: "Forms of writing were not seen as vessels into which different contents could be indifferently poured; form was itself a statement, a content." 
Cited Works

Allen, Michael J.B. "Ficino's Theory of the Five Substances and the Neoplatonists' Parmenides?" The Journal of Medieval and Renaissance Studies 12 (1982): 19-44. Allen, Michael J.B. The Platonism of Marsilio Ficino: A Study of his Phaedrus Commentary, Its Sources and Genesis. Berkeley: The University of California Press, 1984.

Aristotle. Physics, trans. and intro. Robin Waterfield. Oxford and New York: Oxford University Press, 1996

Bächtold-Stäubli, Hanns. Handwörterbuch des deutschen Aberglaubens: herausgegeben unter besonderer Mitwirkung von E. Hoffmann-Krayer. 10 vols. Berlin and Leipzig: De Gruyter, 1927-42.

Boyarin Daniel. Carnal Israel: Reading Sex in Talmudic Culture. Berkeley, Los Angeles, London: University of California Press, 1993.

Bruno, Giordano. Candelaio: Commedia. Pariggi: G. Giuliano, 1582. Facsimile ed. by Eugenio Canone. Florence: Olschki, 1999.

Bruno, Giordano, Candlebearer, trans. and intro. Gino Moliterno. Ottawa: Dovehouse, 2000.

Cavell, Stanley. Disowning Knowledge in Seven Plays of Shakespeare. Cambridge,

UK, and New York: Cambridge University Press, 1987.

Copenhaver, Brain P. and Charles B. Schmitt. Renaissance Philosophy. History of Western Philosophy, 3. Oxford: Oxford University Press, 1992.

Ebbersmeyer Sabrina. Sinnlichkeit und Vernunft. Studien zur Rezeption und Transformation der Liebestheorie Platons in der Renaissance. München: Fink, 2002.

Ficino, Marsilio. Commentaire sur le Banquet de Platon Marsile Ficin, ed. and trans. Raymond Marcel. Paris: Les Belles Lettres, 1956.

Ficino, Marsilio. Théologie platonicienne de l'immortalité des âmes, ed. and trans. Raymond Marcel. 3 vols. Paris: Les Belles Lettres, 1964-72.

Ficino, Marsilio. Commentary on Plato's Symposium on Love, trans. Sears Jayne. Dallas. 2nd ed. rev. Texas: Spring Publications, 1985.

Ficino, Marsilio. Three Books on Life, ed. and transl. Carol V. Kaske and John R. Clark. Binghamton, NY: MRTS/RSA, 1989.

Field, Arthur. The Origins of the Platonic Academy of Florence. Princeton, NJ: Princeton University Press, 1988.

Garvin, Barbara. "The Language of Leone Ebreo's Dialoghi d'amore." Italia. Studi e ricerche sulla storia, la cultura e la letteratura degli Ebrei d'Italia, 13-15 (2000): 181-210.

Guthrie, William K. C.. A History of Greek Philosophy. 8 vols. Cambridge, UK: Cambridge University Press, 1962-1981.

Halperin, David M. "Why is Diotima a Woman? Platonic Eros and the Figuration of Gender" pp. 257-308 in Before Sexuality. The Construction of Erotic Experience in the Ancient Greek World, ed. David M. Halperin, John J. Wingler and Froma Zeitlin. Princeton, NJ: Princeton University Press, 1990.

Halperin, David M. "Platonic Erôs and what Men Call Love" vol. 3, pp. 66-120 in Plato: Critical Assessments, ed. Nicholas D. Smith. 4 vols. London: Routledge, 1999. 
Hankins, James. Plato in the Italian Renaissance. Leiden and New York: E.J. Brill, 1990.

Keßler, Eckhard. "Metaphysics or Empirical Science? The Two Faces of Aristotelian Natural Philosophy in the Sixteenth Century" pp. 79-101 in Renaissance Readings of the Corpus Aristotelicum, ed. Marianne Pade. Copenhagen: Museum Tusculanum Press / University of Copenhagen, 2001.

Kodera, Sergius. Filone und Sofia in Leone Ebreos 'Dialoghi d'amore': Platonische Liebesphilosophie der Renaissance und Judentum. Frankfurt am Main and New York: Peter Lang, 1995.

Kodera, Sergius. "Masculine/Feminine. The Concept of Matter in Leone Ebreo's Dialoghi d'Amore." Zeitsprïnge. Forschungen zur Frühen Neuzeit 7 (2003): 481-517.

Kristeller, Paul Oskar. The Philosophy of Marsilio Ficino, trans. Virginia Conant. New York: Columbia University Press, 1943.

Kristeller, Paul Oskar. Eight Philosophers of the Italian Renaissance. Stanford, CA: Stanford University Press, 1964.

Leone Ebreo. Dialoghi d'amore. Rome: Antonio Blado, 1535. Facsimile edition by Carl Gebhard. Heidelberg: Carl Winter, $1929 .$.

Leone Ebreo. The Philosophy of Love (Dialoghi d'amore), trans. F. Friedeberg-Seeley and Jean H. Barnes. London: Soncino Press, 1937.

Nehamas, Alexander. Virtues of Authenticity: Essays on Plato and Socrates. Princeton, NJ: Princeton University Press, 1999.

Nelson, John Charles. Renaissance Theory of Love: the Context of Giordano Bruno's Eroici furori. New York: Columbia University Press, 1958.

Nussbaum, Martha Craven. The Fragility of Goodness: Luck and Ethics in Greek Tragedy and Philosophy. Cambridge, UK, and New York: Cambridge University Press, 1986.

Nussbaum, Martha Craven. Love's Knowledge: Essays on Philosophy and Literature. Oxford and New York: Oxford University Press, 1990.

Peri, Hiram [a.k.a. Heinz Pflaum]. Die Idee der Liebe: Leone Ebreo. Zwei Habhandlungen zur Geschichte der Philosophie in der Renaissance. Heidelberger Abhandlungen zur Philosophie und ihrer Geschichte, 7. Tübingen: J.C.B. Mohr, 1926.

Perry, Theodore A. "Dialogue and Doctrine in Leone Ebreo's Dialoghi d'amore." Publications of the Modern Language Society of America 88 (1973): 1173-79.

Perry, Theodore A. Erotic Spirituality: The Integrative Tradition from Leone Ebreo to John Donne. University, AL: University of Alabama Press, 1980.

Pico della Mirandola, Giovanni. De hominis dignitate, Heptaplus, De ente et uno: Scritti vari, ed. Eugenio Garin. Florence: Vallecchi, 1942.

Plato. Opera omnia quae extant, trans. Marsilio Ficino. Frankfurt: Apud C. Marnium \& haeredes, 1602.

Plato. Symposium, trans. Robin Waterfield. Oxford, UK, and New York: Oxford University Press, 1994.

Rocke, Michael J. Forbidden Friendships: Homosexuality and Male Culture in Renaissance Florence. Oxford and New York: Oxford University Press, 1996. 
Rossiaud, Jacques. Medieval Prostitution, trans. Lydia G. Cochrane. Oxford and New York: Blackwell, 1988.

Veltri, Giuseppe. "Philo and Sophia. Leone Ebreo's concept of Jewish Philosophy" pp. 55-66 in Cultural Intermediaries. Jewish Intellectuals in Early Modern Italy, ed. David B. Ruderman and Giuseppe Veltri. Philadelphia: University of Pennsylvania Press, 2000.

Walker, Daniel P. Spiritual and Demonic Magic from Ficino to Campanella. London: Warburg Institute, 1958.

Wind, Edgar. Pagan Mysteries in the Renaissance. 2nd ed. rev. London: Faber, 1968. Yavneh, Naomi. "The Spiritual Eroticism of Leone's Hermaprodite" pp. 85-89 in Playing with Gender: A Renaissance Pursuit, ed. Jean R. Brink, Maryanne C. Horowitz and Allison P. Coudert. Urbana, IL: University of Illinois Press, 1991. 